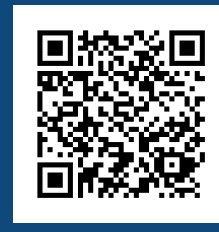

Keywords: Luehea divaricata Irrigation Substrate Forest nursery

Historic: Received 31/01/2018 Accepted 22/06/20I 8

Correspondence: adriflorestal@gmail.com
Adriana Falcão Dutrala+, Maristela Machado Araujo'b, Luciane Almeri Tabaldi ${ }^{\text {lc }}$, Daniele Guarienti Rorato'd, Daniele Rodrigues Gomes ${ }^{l e}$, Felipe Turchetto'f

\section{OPTIMIZATION OF WATER USE IN SEEDLING PRODUCTION OF ARBOREAL SPECIES}

DUTRA, A. F.; ARAUJO, M.M.; TABALDI, L. A.; RORATO, D. G.; GOMES, D. R.;TURCHETTO, F. Optimization of water use in seedling production of arboreal species. CERNE, v. 24, n. 3, p. 20I-208, 2018.

\section{HIGHLIGHTS}

Luehea divaricata seedlings require high irrigation in the nursery.

Substrates used in the production of seedlings of Luehea divaricata should present high water easily available.

Luehea divaricata seedlings can be expedided from the nursery in less time than expected for most native species.

It's possible to produce seedlings of Luehea divaricata with the use of carbonized rice husk.

\section{ABSTRACT}

The quantification of the hydric requirement during the production of quality seedlings is of extreme importance and the substrate used is a mediator of this influence. However, few studies are carried out in this context, particularly on native species such as Luehea divaricata, which has great potential for lumber production and the restoration of riparian forests. The aim of this study was to characterize the survival and growth of $L$. divaricata seedlings in different substrates and under different irrigation schemes. The experimental design used a factorial scheme composed of four formulations of substrate (100T: 100\% turf (peat); $80 \mathrm{~T}: 80 \%$ peat and $20 \%$ carbonized rice husk - $\mathrm{CRH} ; 60 \mathrm{~T}: 60 \%$ peat and $40 \% \mathrm{CRH}$; 40T: $40 \%$ peat and $60 \% \mathrm{CRH}$ ) and six irrigation schemes. Survival, height, stem diameter, aerial dry matter, root and total leaf area, and Dickson Quality Index were evaluated. We observed elevated survival, height, stem diameter, aerial dry matter, and leaf area under an irrigation of $16 \mathrm{~mm}$. day ${ }^{-1}$ with substrates I00T and 80T. The dry matter and Dickson Quality Index, independent of the irrigation, resulted in greater carbon accumulation. Thus, we concluded that substrates based on peat, mixed with up to $20 \%$ $\mathrm{CRH}$, allowed greater seedling growth, facilitating earlier hardening and expedition, under an irrigation scheme of $16 \mathrm{~mm} \cdot$ day $^{-1}$. L. divaricata is a native species that can be considered to have high hydric demand during the seedling production phase. 


\section{INTRODUCTION}

Luehea divaricata Mart. et Zucc., from family Malvaceae family, is a native species of South America, occurring in Brazil, Uruguay, Argentina, Paraguay (USDA, 20I5) and Bolivia (Tropicos, 20I5). The species can be found in areas of riparian forest both in waterlogged soils and in well drained soils (Carvalho et al., 2008), being indicated for restoration of degraded areas and permanent preservation (Carvalho, 2003). Recent study highlighted the medicinal importance of Luehea divaricata, from the extract of leaves, finding the increasing of resistance and cholinergic tonus in living organisms, suggesting that more detailed investigations are required to examine its potential for treating diverse medicinal treatments, such as Alzheimer's (Arantes et al., 20l4).

However, uncontrolled and overly extractive exploration of $L$. divaricata, associated with the reduction in forest area owing to an increase in other land use types, has led to a considerable reduction in the number of its specimens. In this context, Conson et al. (20/3) highlighted the importance of defining strategies for population conservation of $L$. divaricata, including the study of its genetic structure, bearing in mind its importance in reforestation programs.

According to Sarmento and Villela (20I0), concern regarding the environment has fostered an increase in the demand for seeds and seedlings of native species, which constitute basic inputs in recovery, improvement, and biotechnology programs. In parallel, the production of quality seedlings with appropriate planting characteristics is essential for the development of technologies that favor satisfactory plant growth at low costs.

In seedling production in recipients, the substrate and the irrigation scheme are related factors and determine plant development and optimization of nutrient use, because a greater slide applied in substrate with elevated macroporosity, for example, will present greater lixiviation than will another with smaller aeration space. In contrast, substrates with elevated microporosity will retain water to an excessive extent, compromising the oxygenation of the root system and the development of the plant.

According to Regan (20I4), the substrate consists of organic and/or inorganic components, which can be mixed in various proportions to achieve the required physical and chemical properties for the growth of seedlings in the recipient. These components must be available and suited to the kind of recipient used. Thus, the wide use of Sphagnum peat moss as a substrate component, along with carbonized rice husk (CRH) derived from rice processing after harvest, can be alternatives for the production of seedlings in several regions worldwide, taking advantage of the residue generated by the previous component. The composition of the components should mediate reduced water consumption with maximum efficiency for the growth.

Allied to this, Landis and Wilkinson (2009) highlighted that adequate irrigation is fundamental to seedling growth, as the roots do not have access to water other than from the walls of the recipient. However, excessive watering can also be problematic for plant growth and can favor the development of disease in the roots. Landis et al. (2010) highlighted that water functions in several physiological processes and inappropriate application can lead to stresses that can persist after final planting.

Although the acquired knowledge for the production of herbaceous ornamental plants in nursery, in relation to the substrate and irrigation, has only recently been established greater effort with commercial arboreal woody species such as Eucalyptus saligna (Lopes et al., 2007), Eucalyptus dunnii (Navroski et al., 2015), and potential native for reforestation and restoration as Parapiptadenia rigida (Dutra et al., 2016). In this light, the aim of the present study was to identify the effects of different formulations of substrate and a range of irrigation schemes on the survival and initial growth of $L$. divaricata seedlings.

\section{MATERIAL AND METHODS}

The experiment was conducted at Universidade Federal de Santa Maria $\left(29^{\circ} 43^{\prime} \mid 4^{\prime \prime}\right.$ South and 53 $43^{\prime} 17^{\prime \prime}$ West), located in the municipality of Santa Maria, RS. The climate of the region is subtropical, Cfa type, with well distributed rains throughout the year, annual average precipitation of $1,720 \mathrm{~mm}$, and annual average temperature of $19.1^{\circ} \mathrm{C}$, reaching daily average of 24.7 ${ }^{\circ} \mathrm{C}$ in the hottest month (January), which decreases until June and July, reaching a daily average of $13.8^{\circ} \mathrm{C}$ (Heldwein et al., 2009).

The fruits of $L$. divaricata were collected from eight remnant forest trees (29 42'02" South and $53^{\circ} 47^{\prime} / 2$ " West) in the municipality of Santa Maria, RS. The collected material was dried in a ventilated environment, for spontaneous opening, followed by the extraction of seeds. Subsequently, the seeds were stored for a period of 4 months in Kraft paper bags and kept in a cold room at $8{ }^{\circ} \mathrm{C}$ and $80 \%$ relative humidity, being ready for sowing.

The experiment installation was performed in completely randomized blocks, in a factorial scheme with subdivided parcels of 24 seedlings each, considering 
four substrates and six irrigation schemes (RR), with 4 replicates each.

The evaluated substrates were constituted of the commercial substrate Carolina Soil ${ }^{\circledR}$, composed of Sphagnum peat and vermiculite (peat), mixed with the carbonized rice husk (CRH), in the proportions of $100 \%$ peat (I00T), $80 \%$ peat and $20 \% \mathrm{CRH}(80 \mathrm{~T}), 60 \%$ peat and $40 \% \mathrm{CRH}(60 \mathrm{~T})$, or $40 \%$ peat and $60 \% \mathrm{CRH}(40 \mathrm{~T})$.

The physical and chemical analyses of the substrate were performed at the Laboratory of Analysis of Substrates for Plants (Laboratório de Análises de Substratos para Plantas - LASPP), State Foundation of Agriculture and Cattle Raising Research (Fundação Estadual de Pesquisas Agropecuárias) (Table I).

TABLE I Average values of the physical and chemicals properties of substrates based on peat and in combination with carbonized rice husk.

\begin{tabular}{cccccccc}
\hline Substrate & $\begin{array}{c}\mathrm{HD} \\
\left(\mathrm{kg} \cdot \mathrm{m}^{-3}\right)\end{array}$ & $\begin{array}{c}\text { AS } \\
(\% *)\end{array}$ & $\begin{array}{c}\text { WEA } \\
(\%)\end{array}$ & $\begin{array}{c}\mathrm{EC} \\
\left(\mathrm{dS} \cdot \mathrm{m}^{-1}\right)\end{array}$ & Condition & $\mathrm{pH}$ & Condition \\
\hline I00T & 392 & 22.6 & 32.1 & 0.54 & normal & 6.03 & Adequate \\
80T & 278 & 30.6 & 23.7 & 0.41 & normal & 6.08 & Adequate \\
60T & 276 & 45.8 & 19.3 & 0.30 & low & 6.31 & Adequate \\
40T & 279 & 43.3 & 17.1 & 0.21 & low & 6.62 & High \\
\hline
\end{tabular}

In which: 100T:100\% peat; 80 T: $80 \%$ peat 20\% carbonized rice husk; $60 \mathrm{~T}: 60 \%$ peat $40 \%$ carbonized rice husk; $40 \mathrm{~T}: 40 \%$ peat $60 \%$ carbonized rice husk. HD: humid density; AS: aeration space; WEA: water easily available; EC: electrical conductivity; pH: hydrogenionic potential. *Schmitz et al. (2002) limit ideal AS = $30 \%$ and WEA $=24$ to $40 \%$.

The sowing was performed in conical polypropylene tubes with a capacity of $110 \mathrm{~cm}^{3}$, conditioned in plastic trays suspended up to $16 \mathrm{~cm}$ from the ground. During sowing, three seeds were used per recipient, which remained in the greenhouse until the seedling reached a height of about $5 \mathrm{~cm}$ and had grown at least two pairs of leaves. At this point, 82 days after sowing, the seedlings were thinned, keeping only the most vigorous and central seedling. Subsequently, for the purpose of growth, the seedlings were fully exposed to the sun and introduced to different irrigation schemes for 120 days.

The irrigation was established based on the uniformity test of irrigation, which determined the differences between the applied volumes. Bernardo et al. (2006) quoted parameters that quantify the application uniformity of water of irrigation systems, which consider a Coefficient of Uniformity by Christiansen (CUC) above $80 \%$ to be adequate (Christiansen, 1942). In the present study, the CUC value was $88.34 \%$.

The irrigation depths were distributed at different frequencies and schedules, defining in this way six schemes of irrigation: RR4 ( $2 \mathrm{~mm}-8 \mathrm{a} . \mathrm{m}$. and I p.m.), RR8 (2 mm - 8 a.m. and I p.m. and $4 \mathrm{~mm}-3: 20$ p.m.), RRI2 (4 mm - 8:30 a.m., I2:30 p.m., and 3 p.m.), RRI6 (4 mm - 7:45 a.m., I I:30 a.m.; 2 p.m. and 4:45 p.m.), RR20 (4 mm - 8:30 a.m., 12:30h a.m. and 3 p.m., and $8 \mathrm{~mm}$ - 4:50 p.m.), and RR24 (4 mm - 7:45 a.m., I I:30 a.m., 2 p.m., and 4:45 p.m.; and $8 \mathrm{~mm}-$ 5:30 p.m.). During periods of rain, the seedlings were covered with plastic, forming tunnels on the plant beds, to avoid the influence of precipitation.

A monthly evaluation for height $(H)$ was performed for four months, in nine seedlings, with the help of a ruler and stem diameter (SD), using a digital caliper. The survival was evaluated on the 120th day after the irrigation scheme was instituted. During the same experiment, analysis of the leaf area was performed, with the use of three seedlings for each treatment; in which the aerial part was removed with the help of pruning shears, and their leaves were fixed in white paper, recovered by transparent glass, for posterior photograph. A millimeter ruler was used for dimensioning, and the samples were photographed with the use of a digital camera, Sony brand, model DSC T-100, and the images were processed with the help of the program IrfanView ${ }^{\circledR}$ and IrfanView Thumbnails ${ }^{\circledR}$.

In addition to this analysis, three seedlings per repetition were used in the determination of aerial dry matter (ADM) and root dry matter (RDM), where the roots and the aerial part were separated with the help of pruning shears, washed for removing the substrate and conducted to a greenhouse of forced air circulation for 72 hours, at $70{ }^{\circ} \mathrm{C}$. From the data, it was possible to obtain parameters such as the total dry matter (TDM) and the Dickson Quality Index (DQI), calculated using the following formula: TDM $(\mathrm{g}) /[\mathrm{H}(\mathrm{cm}) / \mathrm{SD}(\mathrm{mm})+$ $\operatorname{ADM}(\mathrm{g}) / \operatorname{RDM}(\mathrm{g})]$ (Dickson et al., 1960).

The data was submitted to the analysis of errors normality assumptions by Shapiro-Wilk, and the homogeneity of variance, by Bartlett. This allowed evincing the necessity of transformation of data to subsequently analysis of variance, comparison of means, and analysis of regression, and when necessary, with the help of SISVAR software (Ferreira, 20I I).

\section{RESULTS}

This study highlighted the fact that the interaction of the substrates and irrigation scheme plays a role in the survival of $L$. divaricata seedlings. The lowest rate (93\%) of survival was observed in the substrate $40 \mathrm{~T}$, and the highest (97.2 to 100\%) in the other treatments, and this condition was considered as positive. 
For the height and stem diameter, the substrates and the irrigation schemes, when observed in function of time, presented significant interaction, highlighting the necessity of a


and greater availability of easily available water ( $\cong 23$ to $32 \%$ ) (Table I), as well as an elevated hydric demand ( $16 \mathrm{~mm} \cdot$ day $^{\prime}$ ), which can be observed since the initial phase of the seedling growth (Figure I). Moreover, the analysis of these two variables ( $\mathrm{H}$ and $\mathrm{SD}$ ) demonstrated the possibility of reducing the time of seedlings in a nursery to about 30 days, when we used up to $20 \%$ of $\mathrm{CRH}$ combined with the peat under any irrigation scheme (Figure I A and B), or with a minimum of $40 \%$ of peat at an irrigation intensity of $16 \mathrm{~mm}$.day' (Figure I D and E); under these conditions, seedlings growth was sufficient for rapid expedition $(\mathrm{H}=25 \mathrm{~cm}, \mathrm{SD}=3 \mathrm{~mm})$.

We have elucidated that the substrate $40 \mathrm{~T}$ ( $60 \%$ of $\mathrm{CRH}$ ) at any irrigation scheme presented seedlings with $\mathrm{H}$ and SD shorter than $22 \mathrm{~cm}$ and $4 \mathrm{~cm}$, respectively, I 20 days after the application of the irrigations (Table 2) and they are not able to planting expedition, based on the height variable.
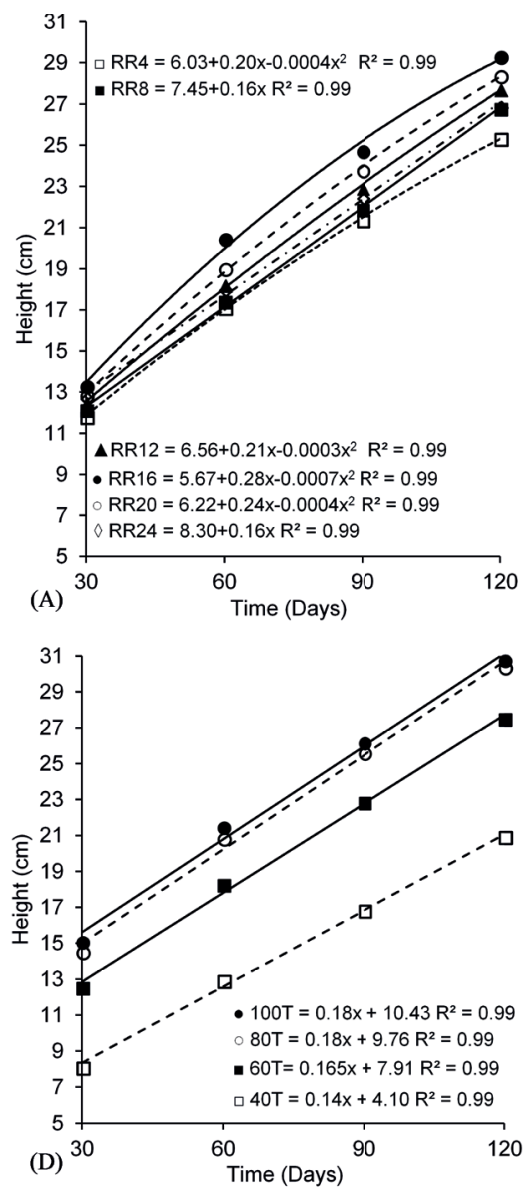

On analyzing the interaction between the factors (substrate and irrigation scheme) on the $120^{\text {th }}$ day, we observed that the greater values of $\mathrm{H}, \mathrm{SD}$, and LA for the $L$. divaricata seedlings occurred in the substrates I00T and $80 \mathrm{~T}$, in the irrigation of $16 \mathrm{~mm} \cdot$ day $^{-1}$ (Table 2), confirming the results observed throughout the experiment when analyzed independently.

At the end of the experiment, we noted that there was no significant interaction between the factors substrate and the irrigation scheme for the dry matter and Dickson Quality Index (DQI). However, for the isolated factors, we noted that the accumulation of biomass was inversely proportional to the increase in the $\mathrm{CRH}$ mixed with the substrate, in which I00T and 80T resulted in greater ADM, RDM, TDM, and DQI (Table 3).

The greatest production of ADM was also observed in seedlings subjected to irrigation at 12, 16 , and $20 \mathrm{~mm} \cdot$ day $^{-1}$ with values of 1.54 ; 1.46 and $1.29 \mathrm{~g}$, respectively, whereas seedlings under hydric restriction


presented the lowest ADM values (Figure 2).


FIGURE I Height $(\mathrm{cm})$ and Stem diameter $(\mathrm{mm})$ Luehea divaricata, respectively $(\mathrm{A}, \mathrm{B})$ at 30, 60, 90 and I 20 days of measurements as a function of the irrigation schemes of 4, 8, I2, I6, 20 and $24 \mathrm{~mm} \cdot$ day ${ }^{1},(C, D)$ at $30,60,90$ and I 20 days of measurements for different substrates evaluated, I00T (I00\% peat), $80 \mathrm{~T}$ (80\% peat $20 \%$ CAC), 60T (60\% peat $40 \%$ CAC) and $40 \mathrm{~T}$ (40\% peat $60 \% \mathrm{CAC})$. With respective equations, coefficient of determination $\left(\mathrm{R}^{2}\right)$. 
TABLE 2 Height $(H)$, Stem Diameter (SD) and Leaf Area (LA) of seedlings of Luehea divaricata, on the 120 days after application of irrigation, in function of different proportions of substrates (I00T - 100\% peat; 80T - $80 \%$ peat and $20 \% \mathrm{CRH} ; 60 \mathrm{~T}-60 \%$ peat and $40 \% \mathrm{CRH}$; and $40 \mathrm{~T}$ - $40 \%$ peat and $60 \% \mathrm{CRH}$ ) and irrigation schemes $\left(\mathrm{mm} \cdot \mathrm{day}^{\prime}\right)$.

\begin{tabular}{|c|c|c|c|c|c|}
\hline \multirow{2}{*}{ Variable } & \multirow{2}{*}{$\begin{array}{l}\text { Irrigation } \\
\text { schemes }\end{array}$} & \multicolumn{4}{|c|}{ Substrate } \\
\hline & & I00T & $80 T$ & $60 T$ & 40T \\
\hline \multirow{6}{*}{$\begin{array}{c}\mathrm{H} \\
(\mathrm{cm})\end{array}$} & 4 & 26.79AC* & 27.0IAc & 25.39Ac & 22. $17 \mathrm{Ba}$ \\
\hline & 8 & $30.60 \mathrm{Ab}$ & $29.26 \mathrm{ABb}$ & $27.68 \mathrm{Bb}$ & $19.63 \mathrm{Cb}$ \\
\hline & 12 & $31.7 \mid \mathrm{Aab}$ & $31.42 \mathrm{Aa}$ & $27.00 \mathrm{Bbc}$ & $20.75 \mathrm{Cab}$ \\
\hline & 16 & $33.44 \mathrm{Aa}$ & $32.47 \mathrm{Aa}$ & $29.69 \mathrm{Ba}$ & $21.66 \mathrm{Ca}$ \\
\hline & 20 & $31.65 \mathrm{Aab}$ & $31.39 \mathrm{Aa}$ & $28.53 \mathrm{Bab}$ & $21.93 \mathrm{Ca}$ \\
\hline & 24 & $30.5 \mathrm{IAb}$ & 30.83Aab & $26.70 \mathrm{Bbc}$ & $19.49 \mathrm{Cb}$ \\
\hline \multirow{6}{*}{$\mathrm{SD}(\mathrm{mm})$} & 4 & 4.89ABd & $5.22 \mathrm{Ad}$ & $4.69 \mathrm{Bd}$ & 3.53Cab \\
\hline & 8 & $5.90 \mathrm{Ac}$ & $5.88 \mathrm{Ac}$ & $5.65 A c$ & $3.75 \mathrm{Ba}$ \\
\hline & 12 & $6.03 \mathrm{Abc}$ & $5 ., 87 \mathrm{Ac}$ & $4.89 \mathrm{Bb}$ & $3.29 \mathrm{Cb}$ \\
\hline & 16 & $6.88 \mathrm{Aa}$ & $6.83 \mathrm{Aa}$ & 6.59Aa & 3.6IBab \\
\hline & 20 & $6.4 \mathrm{IAb}$ & $6.31 \mathrm{Ab}$ & 6. $14 \mathrm{Ab}$ & 3.52Bab \\
\hline & 24 & $6.31 \mathrm{Ab}$ & 6.27Abc & $5.74 \mathrm{Bbc}$ & 3.55Cab \\
\hline \multirow{6}{*}{$\begin{array}{c}\text { LA } \\
\left(\mathrm{cm}^{2} \cdot \text { plant }^{-1}\right)\end{array}$} & 4 & I46.28Ac & $102.19 \mathrm{ABa}$ & $86.98 \mathrm{Bb}$ & $62.60 \mathrm{Bb}$ \\
\hline & 8 & $166.13 \mathrm{Abc}$ & I50.47ABa & I I 2.67ABab & $102.75 \mathrm{Ba}$ \\
\hline & 12 & 191.32Aabc & $=148.26 \mathrm{ABa}$ & I I4.58BCab & 73.47Cab \\
\hline & 16 & $252.77 \mathrm{Aa}$ & $164.23 \mathrm{Ba}$ & I47.14Bab & 56.63Cab \\
\hline & 20 & 225.77Aab & |47.88Ba & I25.57Bab & 99.99Bab \\
\hline & 24 & I80.00Aabc & $=122.46 \mathrm{ABa}$ & $1 / 3.79 \mathrm{Ba}$ & 86.93Bab \\
\hline
\end{tabular}

*Averages followed by the same letter in line (upper case) and in the column (lower case) do not differ among them by the Tukey Test at $5 \%$ of error probability.

TABLE 3 Aerial dry matter (ADM), root (RDM) and total (TDM) (g.plant ${ }^{-1}$ ) and Dickson Quality Index (DQI) of Luehea divaricata seedlings, at I 20 after application of the irrigation, in function of different proportions of substrates (100T - 100\% peat; $80 \mathrm{~T}$ - $80 \%$ peat and $20 \% \mathrm{CRH}$; $60 \mathrm{~T}$ - $60 \%$ peat and $40 \% \mathrm{CRH}$; and $40 \mathrm{~T}$ - $40 \%$ peat and $60 \% \mathrm{CRH})$.

\begin{tabular}{ccccc}
\hline Substrate & ADM & RDM & TDM & DQI \\
\hline $100 \mathrm{~T}$ & $1.64 \mathrm{a}^{*}$ & $1.72 \mathrm{a}$ & $3.36 \mathrm{a}$ & $0.54 \mathrm{a}$ \\
$80 \mathrm{~T}$ & $1.52 \mathrm{a}$ & $1.58 \mathrm{a}$ & $3.10 \mathrm{a}$ & $0.49 \mathrm{ab}$ \\
$60 \mathrm{~T}$ & $1.08 \mathrm{~b}$ & $1.0 \mathrm{~b}$ & $2.28 \mathrm{~b}$ & $0.37 \mathrm{~b}$ \\
$40 \mathrm{~T}$ & $0.59 \mathrm{c}$ & $0.54 \mathrm{c}$ & $1.13 \mathrm{c}$ & $0.17 \mathrm{c}$ \\
\hline
\end{tabular}

*Averages followed by the same letter (lower case) do not differ among them by the Tukey Test at $5 \%$ of error probability.

\section{DISCUSSION}

The substrates in combination with the irrigation schemes were evaluated, except 40T under the irrigation of $24 \mathrm{~mm} \cdot$ day $^{-1}$ (mortality greater than 5\%), resulted in the survival of $L$. divaricata seedlings in accordance with Lopes et al. (2005), who considered a maximum of $5 \%$ as an acceptable loss.

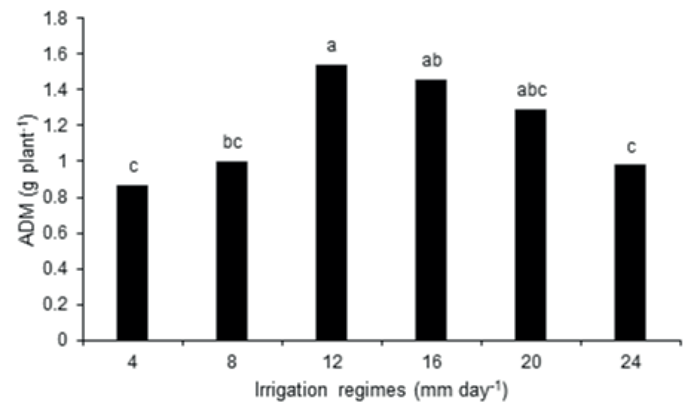

FIGURE 2 Aerial dry matter of Luehea divaricata seedlings, at 120 days after application of irrigation, in function of different irrigation schemes.

When the same authors were evaluating the survival of $E$. grandis seedlings under different levels of irrigation and substrates, they verified that the survival was strongly influenced by the hydric scheme. In this case, the smallest slide brute tested, i.e., $6 \mathrm{~mm}$ daily, applied 3 times a day, resulted in mortality equal or superior to $44 \%$ and reduced growing. However, in the present study, in which the lowest irrigation scheme $\left(4 \mathrm{~mm} \cdot\right.$ day $^{-1}$, applied twice a day) guaranteed a minimum of $97 \%$ of seedling survival at the end of the experiment, except in substrate $40 \mathrm{~T}$ (93\%), indicating that in relation to survival, $L$. divaricata is relatively tolerant to hydric stress.

The most remarkable finding in the present study, corroborated by previously reported results, was that $L$. divaricata seedlings grown in the substrates $100 \mathrm{~T}$ and $80 \mathrm{~T}$ and at an irrigation intensity of $16 \mathrm{~mm}^{-1}$ day $^{-1}$ in the initial phase in the nursery, grew well (Figure I C and D). This fact may be associated to high temperatures during the initial period of study, with a monthly average of 24.7 and $22.8^{\circ} \mathrm{C}$ in February and March, and a maximum of 33.6 and $35.6{ }^{\circ} \mathrm{C}$, respectively. Additionally, the adequate physical properties of the substrate based on peat (Bellé and Kampf, 1993) and the surplus availability of water can have a positive influence in the survival of the seedlings.

This proves that water is important for the development of forest species, and is also a limiting factor for flood tolerant species such as $L$. divaricata (Carvalho et al., 2008), which presented inferior growth under the irrigation intensity of $24 \mathrm{~mm} \cdot$ day $^{-1}$. The plant growth can be affected by the presence of excess of water in the environment and also by hydric deficit. In the first case, the reduction of oxygen occurs, making it difficult for the root to breathe, besides the fact that the high frequency of irrigation can cause nutrient leaching, and in the second, it decreases the hydraulic conductivity, provoking the closing of stomas and reduction in photosynthesis (Ördög and Molnár, 20l I).

Substrates 100T and 80T are ideal possibly because they are associated with the AS that is equal to 
22.6 and $30.6 \%$ and the water easily available (WEA) value of 32.1 and $23.7 \%$, respectively (Table I). The substrates with higher levels of rice husk (60T and 40T), provided on average $40 \%$ more AS and $35 \%$ less of WEA (Table I) because of the fact that the rice husk is a light material and inert to hydration (Guerrini and Trigueiro, 2004). Substrates I00T and 80T being ideal is reinforced by Regan (2014), who recommended the adequate ranges for AS and WEA of substrates to be around $10-30 \%$ and $32.5-22.5 \%$, respectively. In this condition, the dry matter (aerial and root) represented about 1.66 g.plant ${ }^{-1}$, while the total dry matter was of $3.4 \mathrm{~g}$ plant $^{-1}$, demonstrating the equal distribution of the final product of photosynthesis, which is favorable to the plant development.

For the ADM, Silva and Silva (2015) verified that the irrigation used, did not have a significant effect on Piptadenia gonocantha seedlings, as the increment in biomass was attributed to the daily frequency of irrigation and the quality of substrate used. In our study, we also observed that the increment of dry matter was not influenced by the irrigation scheme but only the substrate, in that a higher proportion of CRH (40T) and consequently greater aeration, was harmful to its development. Because the rice husk is made of a material poor in nutrients (Guerrini and Trigueiro, 2004), we observed a low electrical conductivity in substrate 40T $\left(0.21 \mathrm{dS} \cdot \mathrm{m}^{-1}\right)$, its greater proportion in substrate influenced in a negative form in the biomass accumulation in the $L$. divaricata plants.

Similarly, DQI was also indicative of the better quality of the seedlings grown in substrates I00T and 80T (Table 3), independent of the irrigation scheme used. In contrast, with respect to the variables $\mathrm{H}, \mathrm{SD}$, and LA, the irrigation depth applied should be based on the substrate used, and, with exception of substrate 40T_-in which the main component was CRH (60\%) all substrates were appropriate for use so long as the adequate irrigation scheme was used. For substrate 60T, an irrigation intensity of $16 \mathrm{~mm}^{\text {day }}{ }^{-1}$ could be used, because this substrate can support seedlings inside an adequate standard size for expedition in the field, albeit with lower dry matter value and DQI than those of seedlings grown using 100T and 80T.

Based on results reported by Gonçalves et al. (2005), as well as on our practical experience with planting $L$. divaricata in the field, seedlings to be produced in containers (110-180 $\mathrm{cm}^{3}$ of substrate) should have $\mathrm{H}$ and SD equal to or superior to $25 \mathrm{~cm}$ and $3 \mathrm{~mm}$, respectively, with healthy visual aspect, and should not be taller than $35 \mathrm{~cm}$. Under these circumstances, the substrate 40T was again the only one of the assessed substrates to not be appropriate, as indicated by these seedlings having the lowest $\mathrm{H}, \mathrm{RDM}$, and DQI; thus, in the field, seedling growth may be suppressed by competition with invasive plants.

Sasse and Sands (1996) noted significant differences in the diameters of Eucalyptus grandis seedlings subjected to various hydric management; the greater the hydric stress applied, the lower the increase in diameter of the seedlings, corroborating with the obtained in watering of $4 \mathrm{~mm} \cdot$ day'. Thus, as verified by $\mathrm{H}$ values, an irrigation intensity of 16 $\mathrm{mm} \cdot$ day $^{-1}$ was adequate for the initial development (SD) of L. divaricata seedlings.

A high proportion of $\mathrm{CRH}$ was also not favorable for increasing leaf area; thus, the addition of $40 \%$ of $\mathrm{CRH}$, along with the lowest irrigation intensity, was associated with the lowest growth of leaf area. This is possibly a morphological adjustment to reduce the water loss; according to Taiz and Zeiger (2002), high leaf area maximizes incident energy and absorption of $\mathrm{CO}_{2}$, but also lowers the conservation of water in the plant, as the opening of the stomas to capture $\mathrm{CO}_{2}$ is associated with water loss. Under these conditions, photosynthesis is reduced, resulting in lower biomass accumulation in other parts of the plant.

Hermann et al. (1992) emphasized the positive influence of root dry matter in the survival and establishment of seedlings in field, and indicated that this variable is one of most important for nursery studies. Seedlings with greater root development can absorb water and nutrients in adequate amounts, thus determining their survival and performance in the field. In the present study, the highest leaf area was observed in seedlings grown in the substrate 100T, followed by those grown in 80 and 60T (Table 2), and with the highest irrigation intensities, indicating a direct relationship with root systems (Table 3).

Water is indispensable to maintain metabolic homeostasis and the structural integrity of cellular macromolecules. The fundamental role of water in the plant, which in the nursery is provided via the substrate and irrigation, is centered in the fact that metabolic activities and cellular growth depend on the water content in the protoplasm; water has distinct functions in the plant, such as in thermo-regulatory action; in turgidity maintenance and thus in cellular lengthening and growth; in the maintenance of molecular structures; and as a component of chemical and biochemical reactions (Taiz and Zeiger, 2002). Additionally, water acts as a solvent for 
electrolytes and is involved in the assembly and reactivity of native biomolecules (Vyumvuhore et al., 20I5).

However, it is possible to infer that the species presents distinct behaviors in relation to the demand of the several factors involved in its growing, such as the water, for example, finding its best development in great condition, but reducing its growing, conform it moves away of the most adequate condition $\left(16 \mathrm{~mm} \cdot\right.$ day $\left.^{-1}\right)$, so they start tolerating intermediate conditions $(20,12$ and even $8 \mathrm{~mm} \cdot$ day $\left.^{-1}\right)$. In the latter cases, the performance of L. divaricata, while not optimal, was still adequate.

This result confirms that of Dutra et al. (2016) who studied the development of Parapiptadenia rigida seedlings under similar conditions to those in the present study and observed better performance under the lowest irrigation intensity. In this context, the attainment of the best result with the lowest irrigation intensity is attributed to the ecological characteristics of the species under study, which Carvalho (2003) described as being found in drier environments, unlike $L$. divaricata.

Production in native plants in forest nurseries is commonly distributed with respect to species, phase of development, and time of production. Nevertheless, we postulated the importance of recognizing speciesspecific hydric demand to optimize the use of productive spaces in nurseries by spatially grouping species with similar hydric necessities. This directly reduce seedling production costs and allowing greater physiological and sanitary control.

Thus, to obtain seedlings of $L$. divaricata ready for hardening in 90 days, substrates 100T and 80T and an irrigation intensity of $16 \mathrm{~mm} \cdot$ day $^{-1}$ should be used. However, if the seedlings are to be maintained in the nursery up to 120 days, these same substrates should be used with an irrigation intensity of $12 \mathrm{~mm} \cdot$ day $^{\prime}$; this management scheme would result in values of $\mathrm{H}$ and SD within the pre-established standard, as well as higher values for the other analyzed variables. In the second scenario, the definition by the 80T will depend on the cultivation area, which before the possibility of rice husk, would reduce the cost of the substrate.

We considered the high values of $\mathrm{H}, \mathrm{SD}, \mathrm{LA}$, and ADM under irrigation schemes of 12 and $16 \mathrm{~mm} \cdot$ day $^{1}$ to be one of the principal results of our study, because, according to Stowe et al. (20l0), reducing the water content applied in nurseries is important for the management of irrigation and fertilization. A reduction in the quantity of water used for irrigation will affect not only the costs of production but also nutrient loss via leaching, thus decreasing the risk of groundwater contamination (Stowe et al., 2010).
We should highlight that, despite the favorable results in the nursery and indications of success in the field, specific studies are still lacking examining the establishment and development of $L$. divaricata under specific planting conditions, particularly in the context of the considerable variation in environmental conditions that directly affects development. Moreover, the greatest increment is likely to be dependent on factors such as the timing of planting, during the period of highest rainfall in the region, considering the high water demand of the species with relation to the substrate; of care taken at the time of planting, mainly to ensure contact of the roots with the soil; and control after planting of competition with invaders in the first few months after implementation.

\section{CONCLUSION}

Various combinations of substrates and irrigation schemes optimize the survival of $L$. divaricata seedlings. However, the species is demanding in water, presenting limiting growth in conditions of reduced percentage of water easily available, under low or excessive irrigation. The substrates based on peat with until $20 \%$ of carbonized rice husk provide the greatest seedling growth, making them available to the hardening and expedition faster, when associated to the irrigation scheme of $16 \mathrm{~mm} \cdot$ day $^{-1}$. Luehea divaricata is a native species that can be considered with high hydric demand during the phase of seedling production.

\section{REFERENCES}

ARANTES, L. P.; COLLE, D.; MACHADO, M. L.; ZAMBERLAN, D. C.; TASSI, C. L. C.; CRUZ, R. C.; MANFRON, M. P.; ATHAYDE, M. L.; SOARES, F. A. A. Luehea divaricata Mart. anticholinesterase and antioxidant activity in a Caenorhabditis elegans model system. Industrial Crops and Products. v. 62, p. 265-27I, 2014.

BELLÉ, S.; KÄMPF, A. N. Produção de mudas de maracujáamarelo em substratos à base de turfa. Pesquisa Agropecuária Brasileira, v. 28, n. 3, p. 385-390, 1993.

BERNARDO, S.; SOARES, A. A.; MANTOVANI, E. C. Manual de Irrigação. 8. ed. Viçosa, MG: UFV, 625 p., 2006.

CARVALHO, P. E. R. Espécies Arbóreas Brasileiras. Colombo: Embrapa Florestas, 1039p., 2003.

CARVALHO, M. C. C. G.; SILVA, D. C. G.; RUAS, P. M.; MEDRI, M. E.; RUAS, E. A.; RUAS, C. F. Flooding tolerance and genetic diversity in populations of Luehea divaricata. Biologia Plantarum. v. 52, n. 4, p. 77I-774, 2008. 
CHRISTIANSEN, E. J. Irrigation by sprinkling. Berkeley: University of California. I42p., 1942.

CONSON, A. R.O.; RUAS, E. A.; VIEIRA, B. G.; RODRIGUES, L. A.; COSTA, B. F.; BIANCHINI, E.; PRIOLI, A. J.; RUAS, C. F; RUAS, P. M. Genetic structure of the Atlantic Rainforest tree species Luehea divaricata (Malvaceae). Genetica, v. I4I, n. 4-6, p. 205-2I5, 2013.

DICKSON, A.; LEAF, A. L.; HOSNER, J. F. Quality appraisal of white spruce and white pine seedling stock in nurseries. Forestry Chronicle, v.36, n.I, p. I0-13, 1960.

DUTRA, A. F; ARAUJO, M. M.; TURCHETTO, F; RORATO, D. G.; AIMI, S. C.; GOMES, D. R.; NISHIJIMA, T. Influence of the substrate and irrigation scheme on the growth of "angico-vermelho" seedlings. Ciência Rural. v.46, n.6, p. 1007-1013, 2016.

FERREIRA, D. F. Sisvar: a computer statistical analysis system. Ciência e Agrotecnologia. v.35, n.6, p. I039-1042, 201 I.

GUERRINI, I. A.; TRIGUEIRO, R. M. Atributos físicos e químicos de substratos compostos por biossólidos e casca de arroz carbonizada. Revista Brasileira de Ciência do Solo, v. 28, p. I069-1076, 2004.

GONÇALVES, J. L. M. Produção de mudas de espécies nativas: substrato, nutrição, sombreamento e fertilização. In: GONÇALVES, J. L. M., BENEDETTI, V. Nutrição e Fertilização Florestal. Piracicaba: IPEF, p. 310-350, 2005.

HELDWEIN, A. B.; BURIOL, G. A.; STRECK, N. A. O clima de Santa Maria. Ciência \& Ambiente, v.38, p.43-58, 2009.

HERMANN, D. F; DUKE, H. R.; SEREFIM, A. M., DAWSON, L. J. Distribution functions to represent centerpivot water distribution. Transactions of the ASAE, St. Joseph, v.35, n.5, p. I465-1472, 1992.

LANDIS, T. D.; DUMROESE, R. K.; HAASE. D. L. Handling and shipping. In: LANDIS, T. D.; DUMROESE, R. K.; HAASE, D. L. (Eds). The Container Tree Nursery Manual: Seedling, Storage, and Outplanting - v. 7: Agriculture Handbook 674. Washington, DC.: U.S. Department of Agriculture, Forest Service. p. I37-I49. 2010.

LANDIS, T. D.; WILDINSON, K. M. Water Quality and Irrigation. In: DUMROESE, R. K., LUNA, T.; LANDIS, T. D. (Eds). Nursery manual for native plants: A guide for tribal nurseries - Vol. I: Nursery management. Agriculture Handbook 730. Washington, DC.: U.S. Department of Agriculture, Forest Service. p. I77-199, 2009.

LOPES, J. L. W.; GUERRINI, I. A.; SAAD, J. C. C.; SILVA, M. R. Efeitos da irrigação na sobrevivência, transpiração e no teor relativo de água na folha em mudas de Eucalyptus grandis em diferentes substratos. Scientia Forestalis, v.68, p.97-106, 2005.

LOPES, J. L. W.; GUERRINI, I. A.; SAAD, J. C. C. Qualidade de mudas de eucalipto produzidas sob diferentes lâminas de irrigação e dois tipos de substrato. Revista Árvore, v.3I, n.5, p.835-843, 2007.
NAVROSKI, M. C.; ARAUJO, M. M.; FIOR, C. S.; CUNHA, F. S.; BERGHETTI, A. L. P.; PEREIRA, M. O. Uso de hidrogel possibilita redução da irrigação e melhora o crescimento inicial de mudas de Eucalyptus dunnii Maiden. Scientia Forestalis, v. 43, n.106, p.467-476, 2015.

ÖRDÖG, V.; MOLNÁR, Z. Plant Physiology. I I4p., 201 I.

REGAN, R. P. Evaluating Alternative Growing Media Components. In: WILKINSON, K. M.; HAASE, D. L.; PINTO, J. R. (Eds). National Proceedings: Forest and Conservation Nursery Associations - (2013) Fort Collins, CO: U.S. Department of Agriculture, Forest Service, Rocky Mountain Research Station. p. 50-53, 2014.

SARMENTO, M. B.; VILLELA, F. A. Sementes de espécies florestais nativas do Sul do Brasil. Informativo ABRATES, v. 20, n. I,2, p.39-44, 2010.

SASSE, J.; SANDS, R. Comparative responses of cuttings and seedlings of Eucalyptus grandis and Eucalyptus globulus to water stress. Tree Physiology, v. 16, p.287-294, 1996.

SCHMITZ, J. A. K., SOUZA, P. V. D., KÄMPF, N. A. Propriedades químicas e físicas de substratos de origem mineral e orgânica para o cultivo de mudas em recipientes. Ciência Rural, v.32, n.6, p.937-944, 2002.

SILVA, R. B. G.; SILVA, M. R. Nursery water management on initial development and quality of Piptadenia gonoacantha seedlings. Scientia Forestalis, v.43, n.105, p.9I-100, 2015.

STOWE, D. C.; LAMHAMEDI, M. S.; CARLES, S.; FECTEAU, B.; MARGOLIS, H. A.; RENAUD, M.; BERNIER, P. Y. Managing irrigation to reduce nutrient leaching in containerized white spruce seedling production. New Forest, v. 40, n.2. p. I85-204, 2010.

TAIZ, L.; ZEIGER, E. Plant Physiology. 3. ed. Massachussetts: Sinauer Associates, 690p. 2002.

TROPICOS. Missouri Botanical Garden. 20I5. Available at: http:// www.tropicos.org/Name/32200 I I I tab = distribution. Accessed in: 25 november. 2015.

USDA, A. R. S. National Genetic Resources Program. Germplasm Resources Information Network - (GRIN) [Online Database]. National Germplasm Resources Laboratory, Beltsville, Maryland, 2015. Available at: http:// www.ars-grin.gov.4/cgi-bin/npgs/html/taxon.pl?22780. Accessed in: 25 november 2015.

VYUMVUHORE, R.; TFAYLI, A.; BINIEK, K.; DUPLAN, H.; DELALLEAU, A.; MANFAIT, M.; DAUSKARDT, R.; GUFFROY, A. B. The relationship between water loss, mechanical stress, and molecular structure of human stratum corneum ex vivo. Journal of Biophotonics, v. 8, n.3, p.2I7-225, 2015. 